\title{
A quantitative method for detecting meat contamination based on specific polypeptides
}

\author{
Chaoyan Feng ${ }^{1}$, Daokun $\mathrm{Xu}^{2}$, Zhen $\mathrm{Liu}^{2}$, Wenyan $\mathrm{Hu}^{2}$, Jun Yang ${ }^{2}$, and Chunbao $\mathrm{Li}^{1, *}$
}

* Corresponding Author: Chunbao Li Tel: +86-25-84395679, Fax: +86-25-84395679,

E-mail: chunbao.li@njau.edu.cn

${ }^{1}$ Key Laboratory of Meat Processing and Quality Control, MOE; Key Laboratory of Meat Processing, MARA; Jiangsu Collaborative Innovation Center of Meat Production and Processing, Quality and Safety Control; College of Food Science and Technology, Nanjing Agricultural University, 210095,

Nanjing, China

${ }^{2}$ Nanjing institute for Food and Drug

Supervision and Inspection, 210095, China

ORCID

Chaoyan Feng

https://orcid.org/0000-0002-9979-6656 Daokun Xu

https://orcid.org/0000-0002-2024-3574

Zhen Liu

https://orcid.org/0000-0001-7583-9300

Wenyan $\mathrm{Hu}$

https://orcid.org/0000-0002-1880-1354 Jun Yang

https://orcid.org/0000-0002-0847-5815

Chunbao Li

https://orcid.org/0000-0002-4764-1994

Submitted Sept 3, 2020; Revised Nov 1, 2020; Accepted Nov 14, 2020
Objective: This study was aimed to establish a quantitative detection method for meat contamination based on specific polypeptides.

Methods: Thermally stable peptides with good responses were screened by high resolution liquid chromatography tandem mass spectrometry. Standard curves of specific polypeptide were established by triple quadrupole mass spectrometry. Finally, the adulteration of commercial samples was detected according to the standard curve.

Results: Fifteen thermally stable peptides with good responses were screened. The selected specific peptides can be detected stably in raw meat and deep processed meat with the detection limit up to $1 \%$ and have a good linear relationship with the corresponding muscle composition.

Conclusion: This method can be effectively used for quantitative analysis of commercial samples.

Keywords: Meat Contamination; Nano-LC-MS/MS; Specific Peptide

\section{INTRODUCTION}

Meat foods are comprised of protein, fat, minerals, vitamins, and other nutrients, which are an indispensable source of human nutrition. In recent decades, meat consumption per capita has been increasing. However, meat safety is a big challenge in some countries or regions. For example, it is quite often illegal to mix low-priced meat, even out-of-date meat with high-priced beef and lamb [1]. Meat contamination is mainly manifested in three forms. Firstly, other animal meats are mixed in a claimed meat. Secondly, meat is replaced by other animal tissues [2]. Thirdly, non-meat components are mixed [3]. Such problems have resulted in the consumers' serious concerns. Therefore, it is of great significance to develop an accurate, sensitive, and fast method for identifying meat contamination.

In recent years, a lot of qualitative and quantitative techniques have been developed to deal with the problem of meat contamination, including enzyme-linked immunosorbent assay [4-6], near infrared spectroscopy [7,8], electronic tongue [9], electronic nose [10], headspace solid phase microextraction coupled with gas chromatography-mass spectrometry [11], and DNA-based techniques [12-16]. However, these techniques have a relatively low accuracy in meat variety identification and require many samples to establish analytical models. DNA-based methods are not suitable for deeply processed meat products, and it is difficult for the absolute quantification of adulterated components in mixed meat samples.

However, proteomics is an alternative. Montowska and Fornal [17] established triple quadrupole mass spectrometry and multiple reaction monitoring (MRM) model to achieve the absolute quantification of adulterated meat by detecting specific peptide markers in meat (chicken, duck, goose, pork, and beef). Pan et al [18] developed a parallel reaction 
monitoring mass spectrometry method for detecting trace pork in meat mixtures (chicken, sheep, and beef). Five specific peptides from myosin were selected as external markers. Limit of detection (LOD) in mixed meat was up to $0.5 \%$. Prandi et al [19] established a liquid chromatography mass spectrometry (LC-MS) method with good linearity for identification and quantification to discriminate eight different meat products. Compared with other methods, mass spectroscopy can identify specific peptides from different animal samples, in mixed meat samples. Peptides that are tolerant to cooking, baking, drying and sterilization are more suitable for the identification of adulterated meat in processed meat products [20]. However, few data are available on such a technique.

In this study, we established a method for efficiently screening specific polypeptides. In addition, thermally stable polypeptides were applied to detect commercial samples and the detection limit was up to $1 \%$.

\section{MATERIALS AND METHODS}

\section{Screening of specific peptides}

Fresh chicken, duck, pork, beef, and lamb samples were obtained, and visible fat and connective tissue were removed. Half of meats from each species were cooked in an $80^{\circ} \mathrm{C}$ water bath for $60 \mathrm{~min}$. Then the raw and cooked samples were homogenized in $20 \mathrm{~mL} 2 \%$ sodium dodecyl sulfate phosphate buffered saline buffer $(0.1 \mathrm{~mol} / \mathrm{L}, \mathrm{pH} 8.0)$. The homogenization conditions were $9,600 \mathrm{rpm}$ for $30 \mathrm{~s}$, and $13,400 \mathrm{rpm}$ for $30 \mathrm{~s}$, and the interval between two bursts was $30 \mathrm{~s}$. Then, samples were centrifuged at $4^{\circ} \mathrm{C}$ at $4,000 \mathrm{~g}$ for 10 $\mathrm{min}$. The supernatant was collected and filtered through gauze. Protein content in the supernatant was quantified by a commercial BCA kit (Thermo Fisher Scientific, San Jose, CA, USA) according to the manufacturer's instructions.

Protein samples $(200 \mu \mathrm{g})$ were transferred into $10 \mathrm{kDa}$ ultrafiltration tubes and centrifuged at $14,000 \mathrm{~g}$ for $15 \mathrm{~min}$. Then sample buffer $(200 \mu \mathrm{L} 8 \mathrm{M}$ urea, $50 \mathrm{mM}$ Tris-HCl pH8.0) was added and centrifuged again $(14,000 \mathrm{~g}, 15 \mathrm{~min})$. The same sample buffer $(200 \mu \mathrm{L} 8 \mathrm{M}$ urea, $50 \mathrm{mM}$ Tris $-\mathrm{HCl}$, pH8.0) containing $5 \mu \mathrm{L} 1 \mathrm{M}$ dithiothreitol (DTT) was added to reduce disulfide bonds. The mixture was heated at $60^{\circ} \mathrm{C}$ for $60 \mathrm{~min}$, and then centrifuged at 14,000 $\mathrm{g}$ for $15 \mathrm{~min}$. The sample buffer $(200 \mu \mathrm{L} 8 \mathrm{M}$ urea, $50 \mathrm{mM}$ Tris- $\mathrm{HCl}, \mathrm{pH} 8.0)$ containing $20 \mu \mathrm{L} 0.5 \mathrm{M}$ iodoacetamide was mixed and kept in dark for $45 \mathrm{~min}$, and centrifuged again (14,000 g, $15 \mathrm{~min}$ ). Then $200 \mu \mathrm{L} 50 \mathrm{mM} \mathrm{NH}_{4} \mathrm{HCO}_{3}$ (pH7.8) was added and centrifuged at 14,000 $\mathrm{g}$ for $15 \mathrm{~min}$, and the step was repeated once. The bottom tubes were replaced by new ones, and

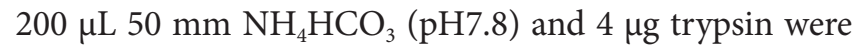
added. Then the samples were incubated at $37^{\circ} \mathrm{C}$ for $16 \mathrm{~h}$. After the incubation, $50 \mu \mathrm{L} 50 \mathrm{mM} \mathrm{NH}_{4} \mathrm{HCO}_{3}(\mathrm{pH} 7.8$ ) was added and centrifuged at $14,000 \mathrm{~g}$ for $25 \mathrm{~min}$. The filtrate was retained and stored at $-20^{\circ} \mathrm{C}$.

The filtrate was loaded onto the extraction head of Monolithic spin columns (MonoSpin, GL Sciences, Tokyo, Japan) for desalination as described previously [21]. Briefly, the column was rinsed stepwise by $100 \mu \mathrm{L} 60 \%$ acetonitrile (ACN) solution ( $0.2 \%$ formic acid), $100 \mu \mathrm{L} 0.2 \%$ formic acid, 100 $\mu \mathrm{L}$ of the former filtrate and $300 \mu \mathrm{L} 0.2 \%$ formic acid. At each step, the samples were centrifuged at 5,000 g for $2 \mathrm{~min}$ and the filtrate was discarded. Then the bottom tubes were replaced by new ones and $100 \mu \mathrm{L} 60 \% \mathrm{ACN}$ solution in $0.2 \%$ formic acid buffer was added to elute the samples by centrifuging at 5,000 $\mathrm{g}$ for $2 \mathrm{~min}$. The desalted samples (the filtrate) were collected, and the concentration was determined by a Nanodrop spectrophotometer (Thermo Fisher Scientific, USA).

Peptide products were separated by reversed phase highperformance liquid chromatography. The nanoliter ion source of the LTQ-orbitrap mass spectrometer (Thermo Fisher Scientific, USA) was used to analyze and detect peptide products. The peptide mixture was loaded into a $\mathrm{C}_{18}$ chromatographic column $(2 \mathrm{~cm} \times 200 \mu \mathrm{m}$, particle size 5 $\mu \mathrm{m})$ by an automatic sampler. Samples were separated by a $\mathrm{C}_{18}$ chromatographic column $(75 \mu \mathrm{m} \times 100 \mathrm{~mm}$, particle size $3 \mu \mathrm{m})$. Mobile phase A ( $0.1 \%$ formic acid solution) and mobile phase B ( $0.1 \%$ formic acid, $84 \%$ acetonitrile aqueous solution) were used. Gradient elution conditions were 0 to $12 \min (97 \%$ A, 3\% B), 12 to $100 \min (72 \%$ A, 28\% B), 100 to $120 \min (45 \% \mathrm{~A}, 55 \% \mathrm{~B}), 122$ to $144 \mathrm{~min}(2 \% \mathrm{~A}, 98 \%$ B), 144 to $160 \mathrm{~min}(97 \% \mathrm{~A}, 3 \% \mathrm{~B})$, and the flow rate was $300 \mathrm{~nL} / \mathrm{min}$. The separated peptides were scanned on the LTQ Orbitrap XL platform. The collision-induced deionization normalized collision energy was set at 35. Fragments were detected in the linear ion trap at normal resolution. The locking mass was set at 445.120020 , and the total scan ranged from 300 to $1,800 \mathrm{~m} / \mathrm{z}$ within $160 \mathrm{~min}$. Proteome Discover -1.4 (Thermo Fisher Scientific, Palo Alto, CA, USA) was used to match peptide level 2 mass spectrometry data (http://www.uniprot.org/) against pork (Sus scrofa), beef (Bos Taurus), chicken (Gallus Gallus), lamb (Ovis Aries), and duck (Anas platyrhynchos) databases. The search parameter was set as follows: the parent ion concentration tolerance was $10 \mathrm{ppm}$, the Oxidation of Met was set as variable modification, and the number of allowed missing cut sites was 2 .

\section{Testing commercial samples}

Triple quadrupole series high performance liquid chromatography and mass spectrometry instrument has a lower resolution, but it is quantitative accurate and has a higher popularity. And thus, the instrument was applied to further screen specific peptides. Triple quadrupole series high per- 
formance liquid chromatography and mass spectrometry (Agilent 6495, Agilent Technologies, Santa Clara, CA, USA) was used for the specificity verification, thermal stability verification, standard curve drawing of specific peptides and test of commercial samples. Raw and cooked samples $\left(80^{\circ} \mathrm{C}\right.$, $1 \mathrm{~h}$ ) (chicken, duck, pork, beef, and lamb) were used for thermal stability verification. Two meat species were mixed at ratios of 0 to 100,20 to 80,40 to 60,60 to 40,80 to 20 and 100 to 0 for standard curve drawing of specific peptides. Three combining regimes were applied by mixing pork with beef, or duck with beef, or chicken with lamb. The specific ingredients were listed in Table 1; Two meat species were mixed at a ratio of 1 to 99 for the specificity verification. Two combining regimes were applied by mixing $1 \%$ chicken with lamb and mixing $1 \%$ duck with beef. The meat samples were treated stepwise with $70 \%$ ethanol, $100 \%$ ethanol, $90 \%$ methanol and deionized water, for $30 \mathrm{~s}$ each time. Then, $1 \mathrm{~g}$ meat samples were added to $5 \mathrm{~mL}$ protein extraction buffer $(7 \mathrm{M}$ urea, $2 \mathrm{M}$ thiourea, $50 \mathrm{mM}$ DTT, 4\% 3-[(3-Cholamidopropyl) dimethylammonio]-1-propane) and homogenized on ice. The homogenate was centrifuged at $12,000 \mathrm{~g}$ for $10 \mathrm{~min}$ at $4^{\circ} \mathrm{C}$. Four volumes of acetone was added and vortexed completely. The samples were centrifuged at 12,000 rpm $4^{\circ} \mathrm{C}$ for $10 \mathrm{~min}$ and the pellets were dried. The dried samples were dissolved in $1 \mathrm{~mL} 1 \mathrm{M}$ urea in $100 \mathrm{mM} \mathrm{NH}_{4} \mathrm{HCO}_{3}$. The protein concentration was determined with a commercial BCA kit (Solarbio, Beijing, China). The protein samples $(100 \mu \mathrm{g})$ were mixed with $50 \mu \mathrm{L} 100 \mathrm{mM} \mathrm{NH}_{4} \mathrm{H}$ $\mathrm{CO}_{3}$ containing $10 \mathrm{mM} \mathrm{DTT}$ and kept at $60^{\circ} \mathrm{C}$ for $30 \mathrm{~min}$. Then $50 \mu \mathrm{L} 100 \mathrm{mM} \mathrm{NH}_{4} \mathrm{HCO}_{3}$ containing $55 \mathrm{mM}$ iodoacetic acid was added and placed in dark for $20 \mathrm{~min}$ at $25^{\circ} \mathrm{C}$. Then the samples were incubated with $10 \mu \mathrm{L}$ trypsin $(0.1 \mathrm{mg} / \mathrm{mL}$ in $25 \mathrm{mM} \mathrm{NH}_{4} \mathrm{HCO}_{3}$ ) for $16 \mathrm{~h}$ at $37^{\circ} \mathrm{C}$. The digestion was stopped by adding $10 \mu \mathrm{L}$ formic acid. A prepared $\mathrm{C}_{18}$ column was loaded and activated by adding $5 \mathrm{~mL}$ methanol and being followed by $5 \mathrm{~mL} 1 \%$ formic acid. The samples were loaded onto the columns and washed with $5 \mathrm{~mL} 5 \%$ methanol (containing $1 \%$ formic acid) and eluted with 5 $\mathrm{mL} 90 \%$ acetonitrile (containing $0.1 \%$ formic acid). Finally, $25 \mu \mathrm{L}$ dimethyl sulfoxide was added and blown dry with nitrogen and finally dissolved in $1 \mathrm{~mL} \mathrm{3 \%}$ acetonitrile in $0.1 \%$ formic acid. The peptides $(20 \mu \mathrm{L})$ were separated in Agilent Poroshell 120 EC-C18 column (particle size: 2.7 $\mu \mathrm{m}, 150 \times 3.0 \mathrm{~mm}$ ) and the flow rate was set at $0.3 \mathrm{~mL} / \mathrm{min}$. Column temperature was set at $35^{\circ} \mathrm{C}$. Mobile phases A (acetonitrile containing $0.1 \%$ formic acid) and B $(0.1 \%$ formic acid) were used. The procedures for gradient elution are listed in Table 2. Mass spectrometry was performed with an electrospray ionization (ESI) ion source (+ion mode). Nitrogen was applied at gas temperature of $250^{\circ} \mathrm{C}$ and sheath temperature of $350^{\circ} \mathrm{C}$ with a flow rate of $12 \mathrm{~L} / \mathrm{min}$ and atomization pressure of 25 psi. Capillary voltage was set at 4,000 V and MRM scanning mode was applied.

\section{Statistical analyses}

The measured data were analyzed by one-way analysis of variance and means were compared by Duncan's multiple comparison under SAS program (version 8.1.2, 2009).

\section{RESULTS AND DISCUSSION}

\section{Efficiency of sample pretreatment}

The matrix in meat samples is complex. In targeted proteomics, efficient protein extraction is one of the most critical steps for analyzing processed meat samples [22]. In both raw meat and cooked meat samples, the protein concentration of beef and lamb was significantly lower than that of duck, which could be due to the presence of more non-protein components in the beef samples (Figure 1A). After cooking, the protein concentration significantly increased for pork samples $(\mathrm{p}<0.01)$ but decreased for beef and lamb samples $(\mathrm{p}<$ 0.001 ). During the cooking process of beef and lamb, some soluble proteins may undergo denaturation and become insoluble [23], and thus the protein concentration is reduced.

After trypsin digestion, the peptide concentration differed greatly with meat species and cooking even if the initial

Table 2. Procedures for gradient elution

\begin{tabular}{lcc}
\hline Time/min & A/\% & B/\% \\
\hline 0.00 & 10 & 90 \\
15.00 & 40 & 60 \\
15.01 & 100 & 0 \\
18.00 & 100 & 0 \\
18.01 & 10 & 90 \\
20.00 & 10 & 90 \\
\hline
\end{tabular}

Table 1. The specific ingredients for standard curve drawing of specific peptides

\begin{tabular}{|c|c|c|c|c|c|c|}
\hline Group & & & The sample c & omponents & & \\
\hline 1 & $100 \%$ pork & $20 \%$ beef $+80 \%$ pork & $40 \%$ beef $+60 \%$ pork & $60 \%$ beef $+40 \%$ pork & $80 \%$ beef $+20 \%$ pork & $100 \%$ beef \\
\hline 2 & $100 \%$ beef & $20 \%$ pork $+80 \%$ beef & $40 \%$ pork $+60 \%$ beef & $60 \%$ pork $+40 \%$ beef & $80 \%$ pork $+20 \%$ beef & $100 \%$ pork \\
\hline 3 & 100\% beef & $20 \%$ duck+80\% beef & $40 \%$ duck $+60 \%$ beef & $60 \%$ duck $+40 \%$ beef & $80 \%$ duck+20\% beef & $100 \%$ duck \\
\hline 4 & $100 \%$ duck & 20\% beef+80\% duck & $40 \%$ beef+60\% duck & $60 \%$ beef+40\% duck & $80 \%$ beef+20\% duck & $100 \%$ beef \\
\hline 5 & 100\% chicken & $20 \%$ lamb+80\% chicken & $40 \%$ lamb+60\% chicken & $60 \%$ lamb $+40 \%$ chicken & $80 \%$ lamb+20\% chicken & $100 \%$ lamb \\
\hline 6 & 100\% lamb & $20 \%$ chicken+80\% lamb & $40 \%$ chicken+60\% lamb & $60 \%$ chicken $+40 \%$ lamb & $80 \%$ chicken+20\% lamb & 100\% chicken \\
\hline
\end{tabular}



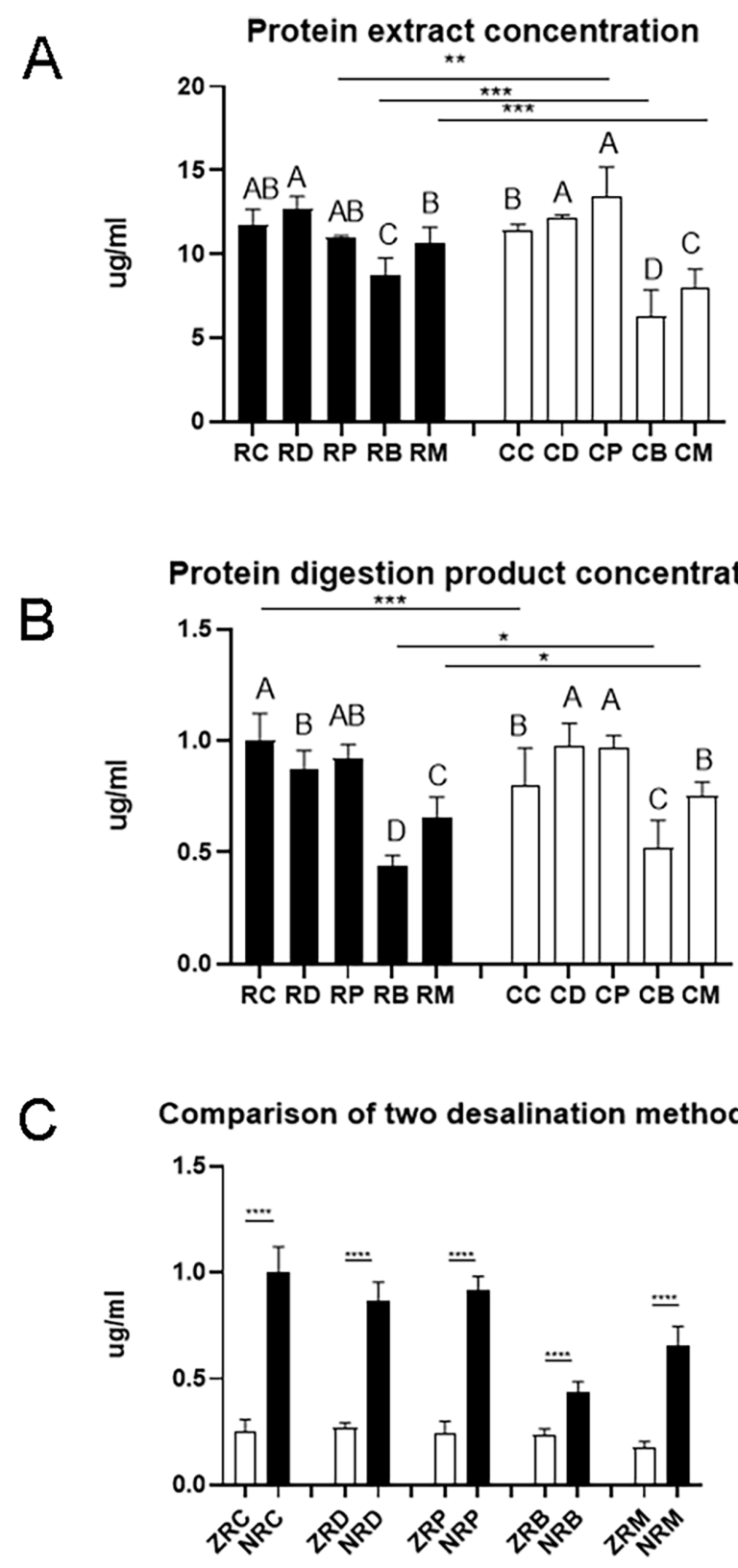

Figure 1. The efficiency of protein extraction varied with the source of samples and the state of meat. (A) The yields of protein extraction were different among meat species and between raw and cook meats. (B) Protein digestion also showed differences among meat species and between raw and cooked meats. (C) Monospin column had a better desalting result. RC, RD, RP, RB and RM, raw chicken, duck, pork, beef and mutton; CC, CD, CP, CB, and CM, cooked chicken, duck, pork, beef and mutton; ZRC, ZRD, ZRP, ZRB and ZRM, the digestion products of raw chicken, duck, pork, beef and mutton passing through the Ziptip column; NRC, RD, RP, RB and RM, the digested products of raw chicken, duck, pork, beef and mutton passing through the Monospin column. A, B, C indicate significant differences among meat species. Data are shown as means and standard deviations.

protein contents were the same (Figure 1B). The peptide concentration was the lowest for beef digestion samples $(\mathrm{p}<0.05)$. The peptide concentration in cooked chicken digestion samples was significantly lower than that in raw chicken digestion samples $(\mathrm{p}<0.001)$. However, the peptide concentration in digestion samples of cooked beef and cooked lamb was significantly higher than their counterparts of raw meat $(p<0.001)$. This indicates that proteins in chicken showed a different vulnerability to heating and subsequent trypsin digestion from proteins in beef and lamb.

Desalting is a critical step for mass spectrometry. Solid phase extraction (SPE) is one of the most common protein desalination methods. Monolithic spin column, a relatively new SPE product that has not been widely used, can enhance sample preparation speed and accommodate small sample 
volumes [24]. The Ziptip $\mathrm{C}_{18}$ column is a traditional method with micropipette-tip SPE. Palmblad and Vogel [25] found that the ZipTip $\mathrm{C}_{18}$ column bound and recovered more sample than the other two types of $\mathrm{C}_{18}$ tips from identical samples using the same loading and elution conditions. Robustness, reproducibility, sensitivity, and economic parameters en- compassing time and costs must be addressed along with the selection of proper SPE product [26]. In the present study, yields of polypeptide products were compared between a traditional Ziptip column and a new monolithic SPE column (Monospin $\mathrm{C}_{18}$ column). Compared with the ziptip column, the Monospin $\mathrm{C}_{18}$ column was more efficient removing salt
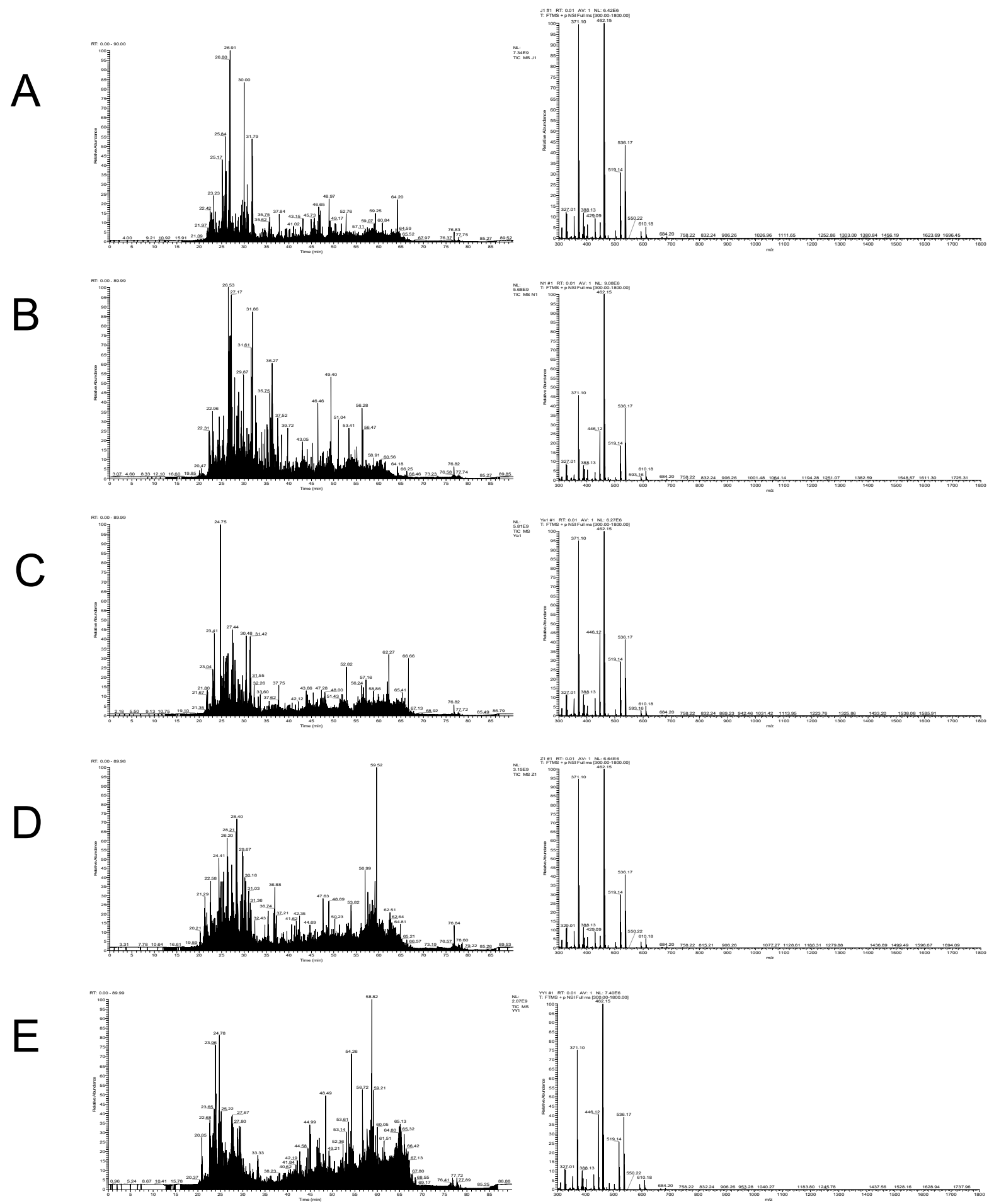

Figure 2. Diagrams of total ion flow and mass spectrometry from digested products of chicken (A), beef (B), duck (C), pork (D), and lamb (E). 
and the peptide yield increased greatly (Figure $1 C$ ). In practice, the operation of the ziptip column is complicated, and only 10 to 20 samples can be prepared in one hour. However, for the Monospin $\mathrm{C}_{18}$ column, it would be possible to prepare up to more than 100 samples per hour with a sample preparation time of 15 to $20 \mathrm{~min}$.

\section{Selection of specific peptides}

Pork, beef, lamb, chicken, and duck have their own specific peptides, which have specific amino acid sequences and are present at high levels in muscle tissues but absent or low in non-muscle tissues. In addition, these peptides are generally of high thermal stability. The traditional method to screen specific peptides was to match the sequences of a specific protein from one meat species to another species in National Center for Biotechnology Information or Uniprot database. The different sequences could be considered as species-specific peptides. However, this screening method does not work well because the screened peptides do not always respond well in an actual test [27-28]. Therefore, finding novel species-specific peptide biomarkers requires comprehensive and detailed observation of meat protein homologies [29]. In the present study, species-specific peptides were screened by trypsin-digestion and high resolution liquid chromatography combined with tandem mass spectrometry.

A total of 794 peptides were identified from the digestion products of raw chicken, corresponding to 1,007, 1,052, 1,571, and 1,181 for raw beef, duck, lamb, and pork, respectively (Figure 2). In digestion products of cooked meat, the numbers of identified peptides increased greatly. A total of 1,218, $1,472,1,194,1,662$, and 1,170 peptides were identified from cooked chicken, beef, duck, lamb, and pork, respectively. A previous study showed a decrease in the number of peptides in cooked samples and a decrease in protein sequence coverage [30]. However, a different phenomenon was found in the present study. In general, heat treatment improves meat degradation potential, which may cause proteins to be broken down more thoroughly into peptides [31].

After careful comparison, 146 peptides were selected specific for chicken, and 218 specific for duck, 181 specific for pork, 93 specific for beef and 111 specific for lamb as well (Supplementary File 1). Notably, these species-specific peptides are not always applicable considering the following factors: high abundance, good signal to noise ratio at low concentrations, high specificity, no missing cleavages, and trypsin specific cleavage sites at both ends [19]. For example, considerable part of peptides can be detected by the LTQorbitrap mass spectrometer but cannot be detected by triple quadrupole mass spectrometry. And thus, further screening and verification were performed.

Ten specific peptides with the highest responses were selected for each species, and the retention time, sub-ion matching degree and corresponding strength of each group of specific ion pairs were investigated. Peptides were selected that were stable in the measured samples. The finally selected specific peptides are shown in Table 3. These peptides are composed of 9 to 17 amino acids. The size range of precursor ion is 513 to $876 \mathrm{kDa}$. Among them, the chickenspecific peptide LDVPISGEPAPTVTWK has been reported $[17,18]$. In addition, other peptides have not been reported and may provide alternative biomarkers for the relevant methods.

\section{Reliability of species-specific peptides}

The thermal stability of selected species-specific peptides was tested. The application of them to the actual samples from raw and cooked meat was evaluated.

MRM transition intensities versus retention time for chicken, beef, duck, pork, and lamb specific peptides are shown in Figure 3. As shown in Figure 3C and D, the re-

Table 3. Selected species-specific peptides

\begin{tabular}{llccccc}
\hline Species & Compound name & Precursor lon & Product Ion & RT & CE & Serial number \\
\hline Beef & TLEDQVNELK & 594.808967 & 845.436323 & 7.142 & 19.4 & SEQ ID NO.1 \\
Beef & GLSDSVSIGPVTVK & 679.879924 & 899.556044 & 9.465 & 22.1 & SEQ ID NO.2 \\
Beef & FLEELLTTQC & 762.871773 & 1006.49861 & 10.549 & 24.6 & SEQ ID NO.3 \\
Chicken & LVSWYDNEFGYSNR & 875.397001 & 1264.52291 & 14.072 & 28.1 & SEQ ID NO.4 \\
Chicken & IGDEFVADLDQLQR & 809.907201 & 1057.56365 & 12.472 & 26.1 & SEQ ID NO.5 \\
Chicken & LDVPISGEPAPTVTWK & 855.45907 & 1382.73144 & 11.566 & 27.5 & SEQ ID NO.6 \\
Chicken & ECQTLVSDVDYR & 742.83793 & 966.489087 & 9.529 & 24 & SEQ ID NO.7 \\
Duck & VVFDDSFDR & 550.256371 & 901.368637 & 8.38 & 18.1 & SEQ ID NO.8 \\
Duck & IVESLQSSLDAEIR & 780.417402 & 1018.51636 & 9.645 & 25.2 & SEQ ID NO.9 \\
Duck & LAILENANVLAR & 648.885344 & 999.558169 & 10.535 & 21.1 & SEQ ID NO.10 \\
Pork & VNVDEVGGEALGR & 657.836048 & 887.458121 & 7.124 & 21.4 & SEQ ID NO.11 \\
Pork & DQGSYEDFVEGLR & 757.841527 & 1127.53677 & 10.346 & 24.5 & SEQ ID NO.12 \\
Lamb & SPPNPENIAPGYSGPLK & 869.443951 & 1342.70014 & 7.954 & 28 & SEQ ID NO.13 \\
Lamb & HVLTTLGER & 513.290548 & 789.446494 & 5.044 & 16.9 & SEQ ID NO.14 \\
Lamb & NLVHIITHGEEKD & 752.891354 & 1041.52112 & 6.188 & 24.3 & SEQ ID NO.15 \\
\hline
\end{tabular}




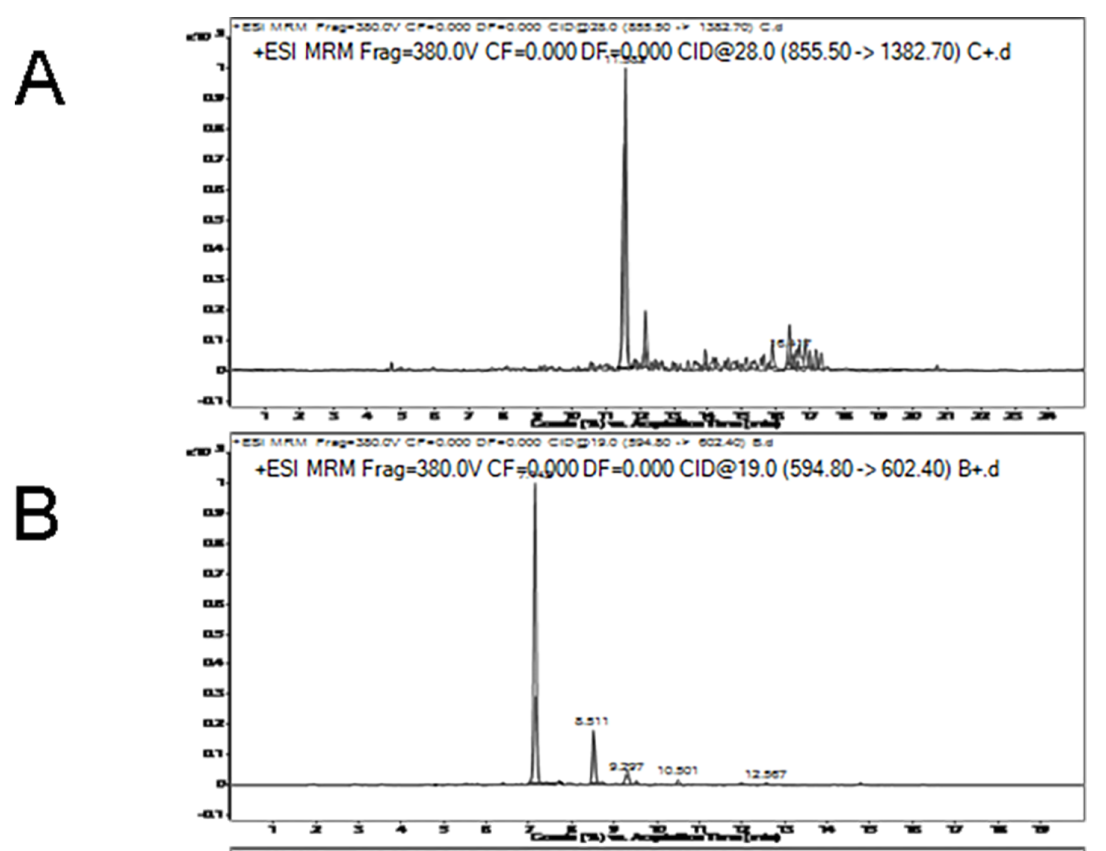

C

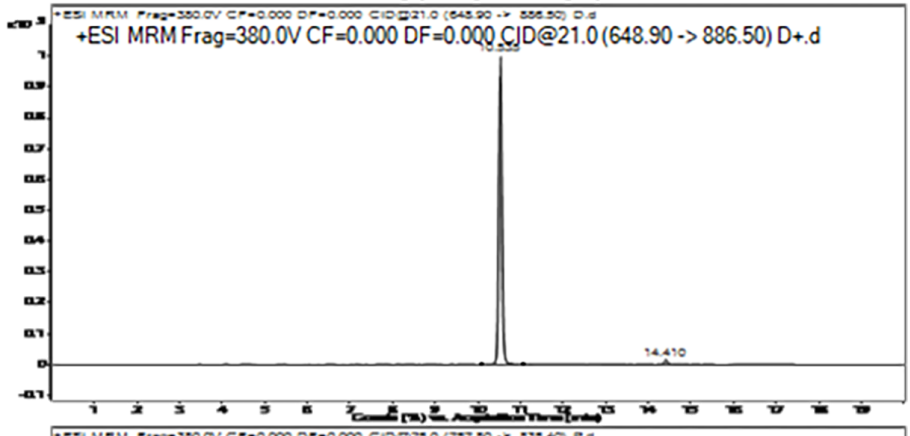

D

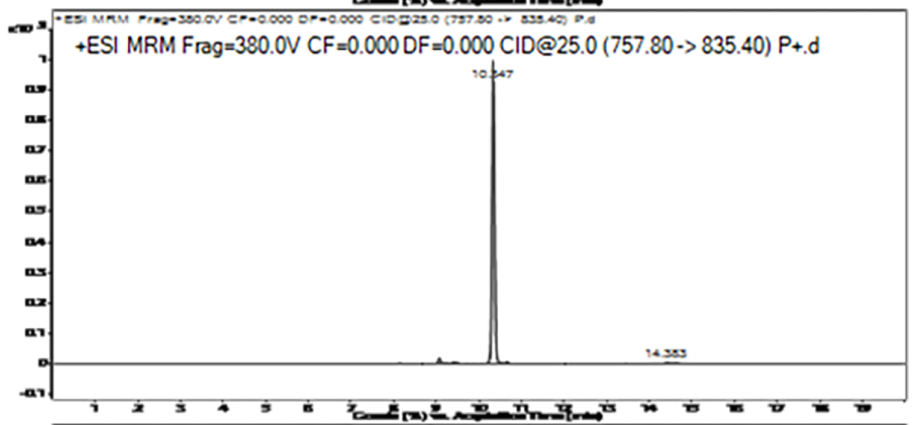

E

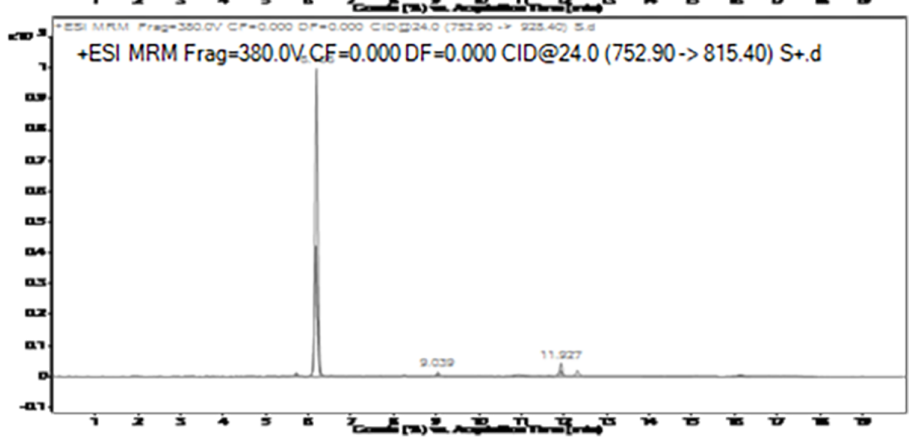

Figure 3. Multiple reaction monitoring (MRM) transition intensities and retention times of specific peptides varied among chicken (A), beef (B), duck (C), pork (D), and lamb (E). 
tention time of the duck-specific peptide (LAILENANVLAR) is 10.535 , which is close to the pork-specific peptide (DQGSYEDFVEGLR) of 10.347. MRM transition intensities of these two peptides were not significantly different between raw meat and cooked meat. The retention times for other specific peptides are shown in Table 3. MRM transition intensities of the chicken, lamb and beef-species peptides, that is, LDVPISGEPAPTVTWK, NLVHIITHGEEKD, and TLEDQVNELK were reduced by nearly $30 \%, 60 \%$, and $70 \%$ from raw meat to cooked meat, respectively. Although

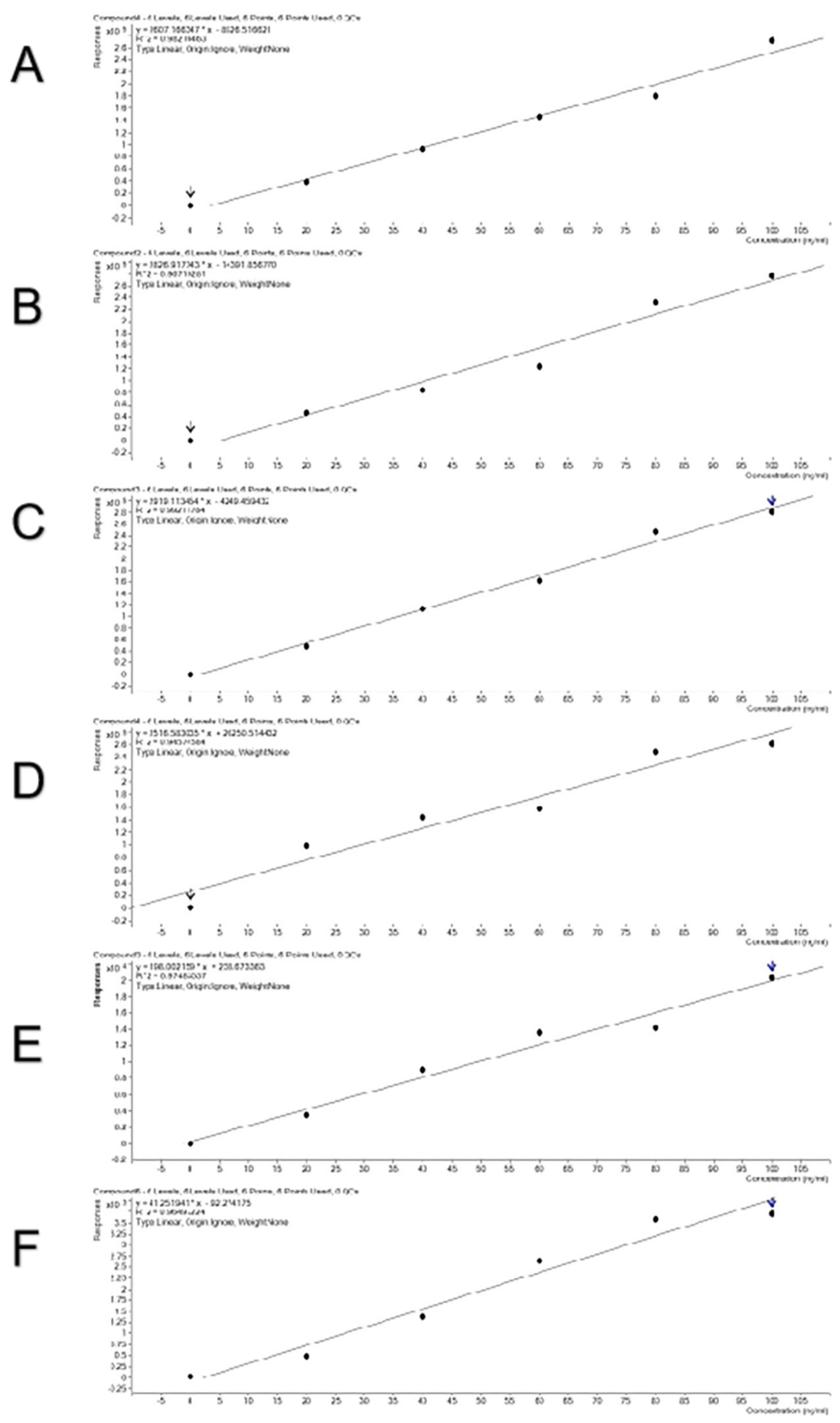

Figure 4. The standard curves of the mixed model for adding beef to pork (A), pork to beef (B), duck to beef (C), beef to duck (D), lamb to chicken $($ E), and chicken to lamb (F). 
the responses of some specific peptides decreased, they are still suitable for quantitative testing.

To verify a good linear relationship between MS intensities of these peptides and their real contents in meat, combinations of two meat species samples were done in a certain proportion and standard curves were obtained (Figure 4). The curves were linear and the $\mathrm{R}^{2}$ values reached 0.946 to 0.992, indicating that the selected species-specific peptides are suitable for quantitative detection. All the standard curves show relatively high reliability with high $\mathrm{R}^{2}$ values. Three combinations of pork and beef, duck and beef, and chicken and lamb did not differ in $\mathrm{R}^{2}$ values. The mixing order did not affect $\mathrm{R}^{2}$ values, either.

To test the LOD of the method, $1 \%$ chicken meat was mixed with $99 \%$ lamb, and $1 \%$ duck meat was mixed with 99\% beef. The results indicated that chicken-specific peptides and duck-specific peptides can be detected in beef and lamb respectively (Figure 5). This indicates that the method

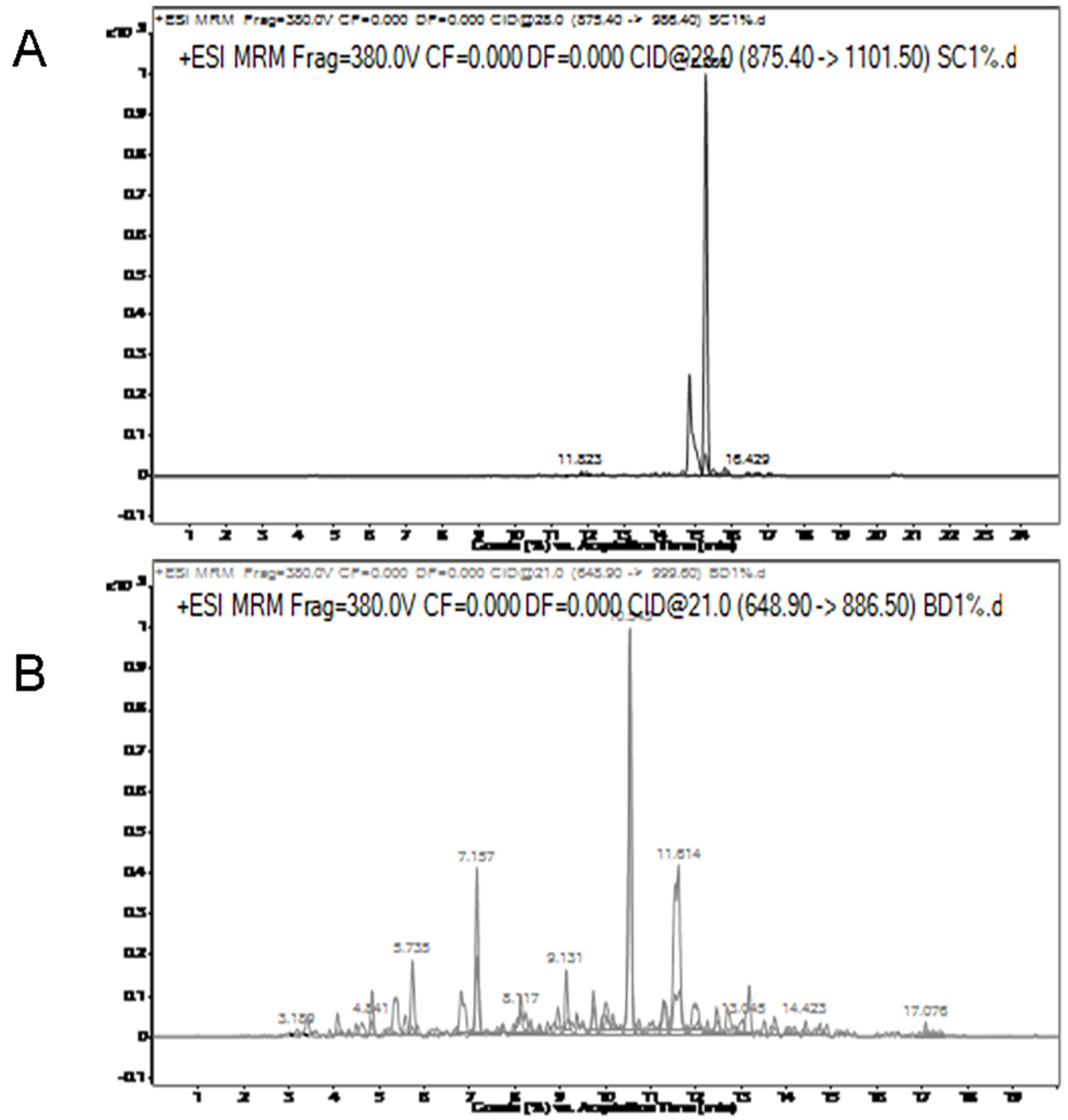

Figure 5. Multiple reaction monitoring (MRM) transition intensities and retention times for 1\% chicken in lamb (A) and $1 \%$ duck in beef (B). 
has a good detection limit. In fact, the percentage of contamination is much higher than $1 \%$.

In addition, several samples obtained from the market were by this method. As shown in Figure 6, pork components (VNVDEVGGEALGR) were found in beef and chicken components (IGDEFVADLDQLQR) were found in lamb. After a single sample preparation, the components of the sample can be determined with a variety of specific peptides. In addition, the specific peptides of the same species can be used at the same time for further verification of the test result.

In summary, we proposed a LC-MS/MS-based method to detect meat contamination using five meat species, i.e., beef, pork, lamb, chicken, and duck. Efficiency of protein extraction showed a great difference among meat species

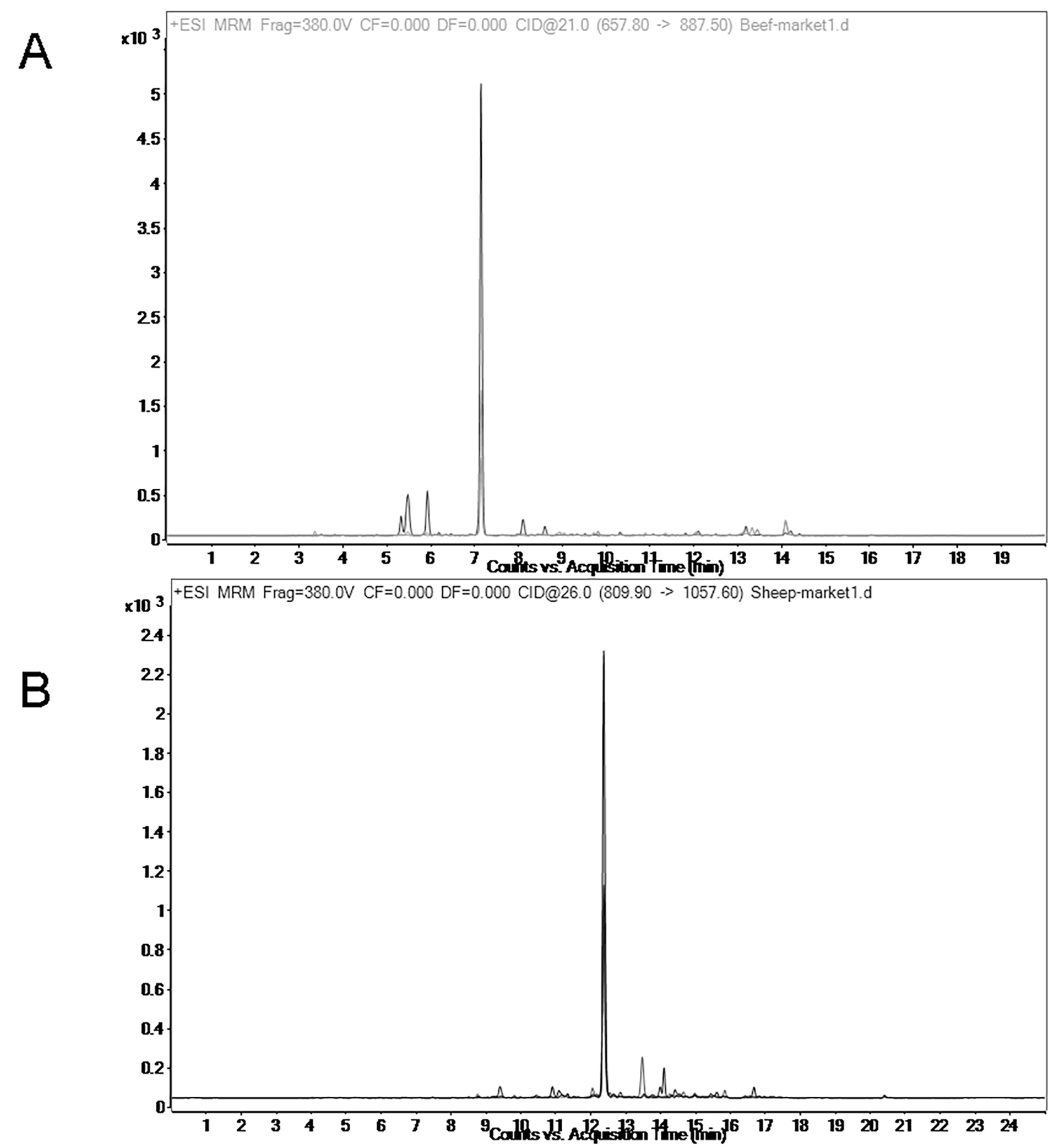

Figure 6. Multiple reaction monitoring transition intensities and retention times for commercial samples. Pork components was found in beef (A) and chicken components was found in lamb (B). 
with lower yields for beef and lamb, and between raw and cooked meat as well. The Monolithic spin column is better to desalt than the Ziptip column. Species-specific peptides were screened by nano LC-LTQ-Orbitrap XL and ESI mass spectrometry. Finally, 15 peptides were selected for identifying meat contamination by triple quadrupole series high performance liquid chromatography and mass spectrometry. The LOD reached $1 \%$. The proposed method is promising for detecting meat contamination.

\section{CONFLICT OF INTEREST}

We certify that there is no conflict of interest with any financial organization regarding the material discussed in the manuscript.

\section{ACKNOWLEDGMENTS}

This study was funded by Jiangsu Department of Science and Technology (BE2016624) and Ministry of Agriculture and Rural Affairs (CARS 35).

\section{REFERENCES}

1. Zhao HT, Feng YZ, Chen W, Jia GF. Application of invasive weed optimization and least square support vector machine for prediction of beef adulteration with spoiled beef based on visible near-infrared (Vis-NIR) hyperspectral imaging. Meat Sci 2019;151:75-81. https://doi.org/10.1016/j.meatsci. 2019.01.010

2. Black C, Chevallier OP, Cooper KM, et al. Rapid detection and specific identification of offals within minced beef samples utilising ambient mass spectrometry. Sci Rep 2019;9:6295. https://doi.org/10.1038/s41598-019-42796-5

3. Jira W, Münch S. A sensitive HPLC-MS/MS screening method for the simultaneous detection of barley, maize, oats, rice, rye and wheat proteins in meat products. Food Chem 2019; 275:214-23. https://doi.org/10.1016/j.foodchem.2018.09. 041

4. Thienes CP, Masiri J, Benoit LA, et al. Quantitative detection of beef contamination in cooked meat products by ELISA. J AOAC Int 2019;102:898-902. https://doi.org/10.5740/jaoacint. 18-0193

5. Ha Y, Thienes CP, Agapov AA, et al. Comparison of ELISA and DNA lateral flow assays for detection of pork, horse, beef, chicken, turkey, and goat contamination in meat products. J AOAC Int 2019;102:189-95. https://doi.org/10.5740/ jaoacint.18-0128

6. Thienes CP, Masiri J, Benoit LA, et al. Quantitative detection of chicken and turkey contamination in cooked meat products by ELISA. J AOAC Int 2019;102:557-63. https://doi. org/10.5740/jaoacint.18-0136
7. Zheng X, Li Y, Wei W, Peng Y. Detection of adulteration with duck meat in minced lamb meat by using visible near-infrared hyperspectral imaging. Meat Sci 2019;149:55-62. https://doi. org/10.1016/j.meatsci.2018.11.005

8. López-Maestresalas A, Insausti K, Jarén C, et al. Detection of minced lamb and beef fraud using NIR spectroscopy. Food Control 2019;98:465-73. https://doi.org/10.1016/j. foodcont.2018.12.003

9. Tian X, Wang J, Shen R, Ma Z, Li M. Discrimination of pork/ chicken adulteration in minced mutton by electronic taste system. Int J Food Sci Technol 2019;54:670-8. https://doi. org/10.1111/ijfs.13977

10. Wang Q, Li L, Ding W, et al. Adulterant identification in mutton by electronic nose and gas chromatography mass spectrometer. Food Control 2019;98:431-8. https://doi.org/ 10.1016/j.foodcont.2018.11.038

11. Pavlidis DE, Mallouchos A, Ercolini D, Panagou EZ, Nychas GJE. A volatilomics approach for off-line discrimination of minced beef and pork meat and their admixture using HSSPME GC/MS in tandem with multivariate data analysis. Meat Sci 2019;151:43-53. https://doi.org/10.1016/j.meatsci. 2019.01.003

12. Qin P, Qiao D, Gao Y, et al. Self-signal-on fluorescent colorimetric protocol for rapid authentication of horsemeat adulterated beef samples with functional designed probes. Int J Food Sci Technnol 2019;54:1752-9. https://doi.org/10. 1111/ijfs. 14068

13. Liu W, Wang X, Tao J, Xi B, Xue M, Sun W. A multiplex PCR assay mediated by universal primers for the detection of adulterated meat in mutton. J. Food Prot 2019;82:325-30. https://doi.org/10.4315/0362-028x.jfp-18-302

14. Li X, Guan Y. Specific identification of the adulterated components in beef or mutton meats using multiplex PCR. J AOAC Int 2019;102:1181-5. https://doi.org/10.5740/jaoacint. 18-0338

15. Köppel R, Ganeshan A, Weber S, et al. Duplex digital PCR for the determination of meat proportions of sausages containing meat from chicken, turkey, horse, cow, pig and sheep. Eur Food Res Technol 2019;245:853-62. https://doi.org/10. 1007/s00217-018-3220-3

16. Qin P, Qu W, Xu J, et al. A sensitive multiplex PCR protocol for simultaneous detection of chicken, duck, and pork in beef samples. J Food Sci Technol 2019;56:1266-74. https:// doi.org/10.1007/s13197-019-03591-2

17. Montowska M, Fornal E. Absolute quantification of targeted meat and allergenic protein additive peptide markers in meat products. Food Chem 2019;274:857-64. https://doi.org/10. 1016/j.foodchem.2018.08.131

18. Pan XD, Chen J, Chen Q, Huang BF, Han JL. Authentication of pork in meat mixtures using PRM mass spectrometry of myosin peptides. RSC Adv 2018;8:11157-62. https://doi.org/ $10.1039 / \mathrm{c} 8 \mathrm{ra} 00926 \mathrm{k}$ 
19. Prandi B, Varani M, Faccini A, et al. Species specific marker peptides for meat authenticity assessment: A multispecies quantitative approach applied to Bolognese sauce. Food Control 2019;97:15-24. https://doi.org/10.1016/j.foodcont. 2018.10.016

20. Fornal E, Montowska M. Species-specific peptide-based liquid chromatography mass spectrometry monitoring of three poultry species in processed meat products. Food Chem 2019;283:489-98. https://doi.org/10.1016/j.foodchem. 2019.01.074

21. Nakamoto A, Nishida M, Saito T, et al. Monolithic silica spin column extraction and simultaneous derivatization of amphetamines and 3,4-methylenedioxyamphetamines in human urine for gas chromatographic-mass spectrometric detection. Anal Chim Acta 2010;661:42-6. https://doi.org/ 10.1016/j.aca.2009.12.013

22. Von Bargen C, Brockmeyer J, Humpf HU. Meat authentication: a new HPLC-MS/MS based method for the fast and sensitive detection of horse and pork in highly processed food. J Agric Food Chem 2014;62:9428-35. https://doi.org/ $10.1021 / \mathrm{j} 5503468 \mathrm{t}$

23. Sentandreu MA, Fraser PD, Halket J, Patel R, Bramley PM. A proteomic-based approach for detection of chicken in meat mixes. J Proteome Res 2010;9:3374-83. https://doi. org/10.1021/pr9008942

24. Bunch DR, Wang S. Applications of monolithic solid-phase extraction in chromatography-based clinical chemistry assays. Anal Bioanal Chem 2013;405:3021-33. https://doi. org/10.1007/s00216-013-6761-0

25. Palmblad M, Vogel JS. Quantitation of binding, recovery and desalting efficiency of peptides and proteins in solid phase extraction micropipette tips. J Chromatogr B 2005; 814:309-13. https://doi.org/10.1016/j.jchromb.2004.10.052

26. Schmelter C, Funke S, Treml J, et al. Comparison of two solid-phase extraction (spe) methods for the identification and quantification of porcine retinal protein markers by LC-MS/MS. Int J Mol Sci 2018;19:3847. https://doi.org/10. 3390/ijms19123847

27. Watson AD, Gunning Y, Rigby NM, Philo M, Kemsley EK. Meat authentication via multiple reaction monitoring mass spectrometry of myoglobin peptides. Anal Chem 2015;87: 10315-22. https://doi.org/10.1021/acs.analchem.5b02318

28. Li Y, Zhang Y, Li H, Zhao W, Guo W, Wang S. Simultaneous determination of heat stable peptides for eight animal and plant species in meat products using UPLC-MS/MS method. Food Chem 2018;245:125-31. https://doi.org/10.1016/j.food chem.2017.09.066

29. Wang GJ, Zhou GY, Ren HW, et al. Peptide biomarkers identified by LC-MS in processed meats of five animal species. J Food Compost Anal 2018;73:47-54. https://doi.org/10.1016/j. jfca.2018.07.004

30. Montowska M, Fornal E. Label-free quantification of meat proteins for evaluation of species composition of processed meat products. Food Chem 2017;237:1092-100. https://doi. org/10.1016/j.foodchem.2017.06.059

31. Bax ML, Aubry L, Ferreira C, et al. Cooking temperature is a key determinant of in vitro meat protein digestion rate: investigation of underlying mechanisms. J Agric Food Chem 2012;60:2569-76. https://doi.org/10.1021/jf205280y 